7. Brokenshire T, Symonds D, Reynolds R, Doggett S, Geary M, Russell R. A cluster of locally-acquired Ross River virus infections in outer Western Sydney. NS W Public Health Bull 2000; 11: 132-4.

8. Hawkes RA, Boughton CR, Naim HM, Stallman ND. A major outbreak of epidemic polyarthritis in New South Wales during the summer of 1983-1984. Med J Aust 1985; 143: 330-33.

9. Hills SL, Sheriden JW. The epidemiology of Barmah Forest virus in Queensland. Arbo Res Aust 1997; 7: 95-99.

10. Russell RC, Cloonan MJ, Doggett SL, Clancy J, Haniotis J, Wells P, et al. Surveillance of arboviruses and vectors in NSW, 1993-1996. Arbo Res Aust 1997; 7: 228-34.

11. Ryan PA, Kay BH. Vector competence of mosquitoes (Diptera: Culicidae) from Maroochy Shire, Australia, for Barmah Forest virus. J Med Entomol 1999; 36: 856-60.
12. Passmore J, O'Grady KA, Moran R, Wishart W. An outbreak of Barmah Forest virus disease in Victoria. Commun Dis Intell 2002; 26: 600-4.

13. Broom A, Sturrock K, vanHeuzen B, Lindsay M, Smith D. Seroconversions in sentinel chickens provide an early warning of Murray Valley Encephalitis virus activity in Western Australia. Arbo Res Aust 2001; 8: 43-7.

14. Forbes JA. Murray Valley encephalitis 1974: also the epidemic variance since 1914 and predisposing rainfall patterns. Sydney: Australasian Medical Publishing Company, 1978.

15. The New South Wales Arbovirus Surveillance and Mosquito Monitoring Program website. Menindee Results. Available at www.arbovirus.health.nsw.gov.au/areas/arbovirus/results/ menindee/menindee.htm. Accessed February 2004.

16. Russell RC. Constructed wetlands in Australia: concerns and constraints, compromises and complements for effective mosquito management. Arbo Res Aust 2000; 8: 314-23. 渎

\title{
RECENT INCREASES IN THE NOTIFICATION OF BARMAH FOREST VIRUS INFECTIONS IN NEW SOUTH WALES
}

\section{Lara Harvey}

NSW Public Health Officer Training Program

NSW Department of Health

\author{
Dominic Dwyer \\ Centre for Infectious Diseases and Microbiology \\ Laboratory Services \\ Institute of Clinical Pathology and Medical Research, \\ Westmead
}

Infection due to Barmah Forest virus (BFV) is an emerging problem in Australia, ${ }^{1}$ with increased numbers of cases being reported. ${ }^{2-5} \mathrm{BFV}$ is a mosquito-borne arbovirus from the Togaviridae family. The virus was first isolated in 1974 from the Barmah State Forest in the Murray Valley region of the Victoria-New South Wales border, ${ }^{6}$ and was first shown to be pathogenic to humans in $1988 .^{7}$ Symptoms of acute human infection may include rash, arthralgia, myalgia, lethargy and fever, ${ }^{3-5,8}$ and are similar to symptoms caused by Ross River virus infection. However, rash is more common and florid, and joint disease is less severe, in BFV disease than in Ross River virus disease. ${ }^{9}$ In a study of BFV cases on the mid-north coast of New South Wales, ${ }^{3}$ over half of all cases reported time off work and an illness that lasted more than 6 months. $\mathrm{BFV}$ disease is therefore associated with a significant burden of illness and is of public health concern. This article describes trends in the notification rates for BFV disease in New South Wales since it was made notifiable in 1991.

\section{METHODS}

Under the NSW Public Health Act 1991, all laboratories must notify suspected cases of BFV infection to the local public health unit. The case definition for a suspected case is a person in whom there are demonstrated specific IgM antibodies to BFV in cerebral spinal fluid or in serum collected within 14 days of onset of symptoms. ${ }^{10}$ Public health unit staff record case details on a confidential statewide database. All cases notified from 1991 to 2003 were geocoded and entered into MapInfo Professional version 7.0 software, ${ }^{11}$ to highlight geographical location of the disease. Only cases notified between 1995 and 2003 were used in the analysis of case characteristics, because of the probability of underreporting and poor data quality in earlier years. ${ }^{12}$ Incidence rates were calculated using the average of the estimated mid-year population for each of the years 1995 to 2003. National data was obtained from the National Notifiable Diseases Surveillance System, ${ }^{13}$ which is available on the Australian Government Department of Health and Ageing website at www.cda.gov.au/surveil.

\section{RESULTS}

For the period 1991-2003 there were 2,527 notifications of BFV infection in New South Wales residents. Before 1995, there were few BFV notifications in the State each year, with 6 cases in 1991, 6 cases in 1992, 25 cases in 1993, and 40 cases in 1994.

In 1995, the number of notifications increased to 271. Of these cases, 122 were resident in the Southern Area Health Service, with 30 per cent of these living in Batemans Bay. ${ }^{2}$

Between 1995 and 2000, there has been continuous BFV activity reported on the north coast of New South Wales, and in the Mid North Coast and Northern Rivers Area Health Services. In 1999, there was a small increase in 
number of cases reported on the south coast in the Illawarra and Southern Area Health Services.

The numbers of notifications rose again in 2001 (402 cases), mainly involving residents of the Mid North Coast and Northern Rivers Area Health Services (Table 1). Since 2001, the number of notifications of BFV infection has been steadily increasing, with 309 cases reported in the Northern Rivers Area Health Service and 303 cases in the Mid North Coast Area Health Service to the end of 2003. There was a large increase in notifications from the Hunter Area Health Service in 2002 (101 cases).

For the period 1995 to 2003, the average annual incidence of BFV infection was 4.2 per 100,000 persons in New
South Wales. BFV infection is predominantly rural in distribution, with the average annual incidence in rural health areas being 9.9/100,000 compared with 0.2/ 100,000 in the metropolitan health areas. The highest incident rates were reported from Southern Area Health Service $(68.8 / 100,000)$ in 1995 , the Mid North Coast Area Health Service $(81.7 / 100,000)$ in 2001 , and the Northern Rivers Area Health Service $(96.4 / 100,000)$ in 2003 (Table 1).

There is a coastal distribution of cases, with the majority of cases restricted to regions east of the Great Dividing Range as shown in Figure 1. However, despite the coastal predominance, there were reported cases in the Far West

\section{TABLE 1}

BARMAH FOREST VIRUS INFECTION, NUMBER OF NOTIFICATIONS AND INCIDENCE RATES PER 100,000 PERSONS BY AREA HEALTH SERVICE OF RESIDENCE, NEW SOUTH WALES, 1996-2003

\begin{tabular}{|c|c|c|c|c|c|c|c|c|c|c|c|}
\hline Health area & & 1995 & 1996 & 1997 & 1998 & 1999 & 2000 & 2001 & 2002 & 2003 & Total \\
\hline \multirow[t]{2}{*}{ CSA } & No. & 4 & 0 & 1 & 0 & 0 & 1 & 0 & 1 & 2 & 9 \\
\hline & Rate & 0.9 & 0 & 0.2 & 0 & 0 & 0.2 & 0 & 0.2 & 0.4 & \\
\hline \multirow[t]{2}{*}{ NSA } & No. & 2 & 2 & 3 & 2 & 2 & 0 & 1 & 2 & 1 & 15 \\
\hline & Rate & 0.3 & 0.3 & 0.4 & 0.3 & 0.3 & 0 & 0.1 & 0.3 & 0.1 & \\
\hline \multirow[t]{2}{*}{ SES } & No. & 1 & 1 & 7 & 0 & 1 & 3 & 0 & 0 & 1 & 14 \\
\hline & Rate & 0.1 & 0.1 & 0.9 & 0 & 0.1 & 0.4 & 0 & 0 & 0.1 & \\
\hline \multirow[t]{2}{*}{ WSA } & No. & 1 & 1 & 1 & 0 & 1 & 1 & 1 & 2 & 3 & 11 \\
\hline & Rate & 0.2 & 0.2 & 0.2 & 0 & 0.1 & 0.1 & 0.1 & 0.3 & 0.4 & \\
\hline \multirow[t]{2}{*}{ SWS } & No. & 0 & 1 & 0 & 0 & 2 & 0 & 2 & 2 & 0 & 7 \\
\hline & Rate & 0 & 0.1 & 0 & 0 & 0.3 & 0 & 0.3 & 0.2 & 0 & \\
\hline \multirow[t]{2}{*}{ WEN } & No. & 0 & 1 & 1 & 2 & 0 & 0 & 1 & 2 & 1 & 8 \\
\hline & Rate & 0 & 0.3 & 0.3 & 0.6 & 0 & 0 & 0.3 & 0.6 & 0.3 & \\
\hline \multirow[t]{2}{*}{ CCA } & No. & 0 & 1 & 0 & 0 & 3 & 3 & 1 & 21 & 7 & 36 \\
\hline & Rate & 0 & 0.4 & 0 & 0 & 1 & 1 & 0.3 & 6.9 & 2.3 & \\
\hline \multirow[t]{2}{*}{ ILL } & No. & 12 & 2 & 7 & 7 & 37 & 15 & 20 & 8 & 4 & 112 \\
\hline & Rate & 3.6 & 0.6 & 2.1 & 2.1 & 10.7 & 4.3 & 5.7 & 2.3 & 1.1 & \\
\hline \multirow[t]{2}{*}{ HUN } & No. & 2 & 1 & 4 & 7 & 11 & 12 & 8 & 101 & 20 & 166 \\
\hline & Rate & 0.4 & 0.2 & 0.8 & 1.3 & 2.1 & 2.2 & 1.5 & 18.5 & 3.7 & \\
\hline \multirow[t]{2}{*}{ SA } & No. & 122 & 4 & 2 & 3 & 27 & 10 & 31 & 9 & 9 & 217 \\
\hline & Rate & 68.8 & 2.2 & 1.1 & 1.7 & 14.9 & 5.5 & 16.7 & 4.8 & 4.8 & \\
\hline \multirow[t]{2}{*}{ GMA } & No. & 2 & 1 & 9 & 7 & 16 & 4 & 3 & 3 & 3 & 48 \\
\hline & Rate & 0.8 & 0.4 & 3.5 & 2.7 & 6.3 & 1.6 & 1.2 & 1.2 & 1.2 & \\
\hline \multirow[t]{2}{*}{ NEA } & No. & 3 & 5 & 5 & 1 & 7 & 4 & 5 & 7 & 8 & 45 \\
\hline & Rate & 1.7 & 2.8 & 2.8 & 0.6 & 4 & 2.3 & 2.9 & 4 & 4.6 & \\
\hline \multirow[t]{2}{*}{ MWA } & No. & 0 & 0 & 2 & 0 & 2 & 2 & 1 & 0 & 3 & 10 \\
\hline & Rate & 0 & 0 & 1.2 & 0 & 1.2 & 1.2 & 0.6 & 0 & 1.8 & \\
\hline \multirow[t]{2}{*}{ FWA } & No. & 0 & 3 & 4 & 9 & 2 & 3 & 7 & 5 & 2 & 35 \\
\hline & Rate. & 0 & 6 & 8.1 & 18.4 & 4.1 & 6.3 & 14.5 & 10.4 & 4.2 & \\
\hline \multirow[t]{2}{*}{ MAC } & No. & 3 & 1 & 2 & 2 & 1 & 3 & 3 & 2 & 1 & 18 \\
\hline & Rate & 2.9 & 1 & 1.9 & 1.9 & 1 & 2.9 & 2.9 & 1.9 & 0.9 & \\
\hline \multirow[t]{2}{*}{ MNC } & No. & 71 & 61 & 96 & 50 & 79 & 94 & 216 & 181 & 122 & 970 \\
\hline & Rate & 29 & 24.6 & 38.2 & 19.6 & 30.7 & 36.1 & 81.7 & 67.7 & 45.1 & \\
\hline \multirow[t]{2}{*}{ NRA } & No. & 48 & 87 & 40 & 44 & 58 & 40 & 102 & 45 & 264 & 728 \\
\hline & Rate & 19.6 & 35.1 & 15.9 & 17.3 & 22.6 & 15.4 & 38.3 & 16.7 & 96.4 & \\
\hline Total & & 271 & 172 & 184 & 134 & 249 & 195 & 402 & 391 & 451 & 2449 \\
\hline \multicolumn{12}{|c|}{$\begin{array}{l}\text { CSA = Central Sydney Area, SWS = South Western Sydney Area, HUN = Hunter Area, MWA = Mid Western Area, NRA = Northern } \\
\text { Rivers Area, NSA = Northern Sydney Area, WEN = Wentworth Area, SA = Southern Area, FWA = Far West Area, SES }=\text { South } \\
\text { Eastern Sydney Area, CCA = Central Coast Area, GMA }=\text { Greater Murray Area, MAC = Macquarie Area, WSA = Western Sydney } \\
\text { Area, ILL = Illawarra Area, NEA = New England Area, MNC = North Coast Area }\end{array}$} \\
\hline \multicolumn{12}{|c|}{ Source: Graphical Online Data Surveillance and Evaluation for Notifiable Diseases (GODSEND). Communicable Diseases B } \\
\hline
\end{tabular}


Area Health Service in 1998 (18.4/100,000), 2001 (14.5/ $100,000)$, and $2002(10.4 / 100,000)$.

A seasonal variation is evident from Figure 2, with the most common season of illness being late summer to early autumn.

The age range for BFV disease cases was 2 months to 98 years, with the median age group being 45-49 years. Slightly more male ( 51 per cent) than female cases were reported (Figure 3 ).

At the national level, there were 7,518 notifications from 1995 to 2003. Fifty-seven per cent of these notifications were from Queensland, 32 per cent from New South Wales, 5 per cent from Western Australia, 3 per cent from Victoria, and 3 per cent from the Northern Territory (Figure 4).

\section{DISCUSSION}

Annual notifications of BFV infection in New South Wales have increased from 6 in 1991 to 451 in 2003. The first reported major outbreak of human disease resulting from BFV infection occurred in 1995 on the south coast, with the focus of activity around Batemans Bay. In total, 135 cases were identified from this outbreak. There was little BFV activity reported on the south coast after 1995. Since 2001, the majority of notifications have been in people resident on the north coast. Thus the distribution of notified cases in the state is predominantly coastal, a finding that is supported by serosurveys undertaken in

\section{FIGURE 1}

\section{DISTRIBUTION OF CASES OF BARMAH FOREST VIRUS INFECTION, NEW SOUTH WALES, 1991-2003.}

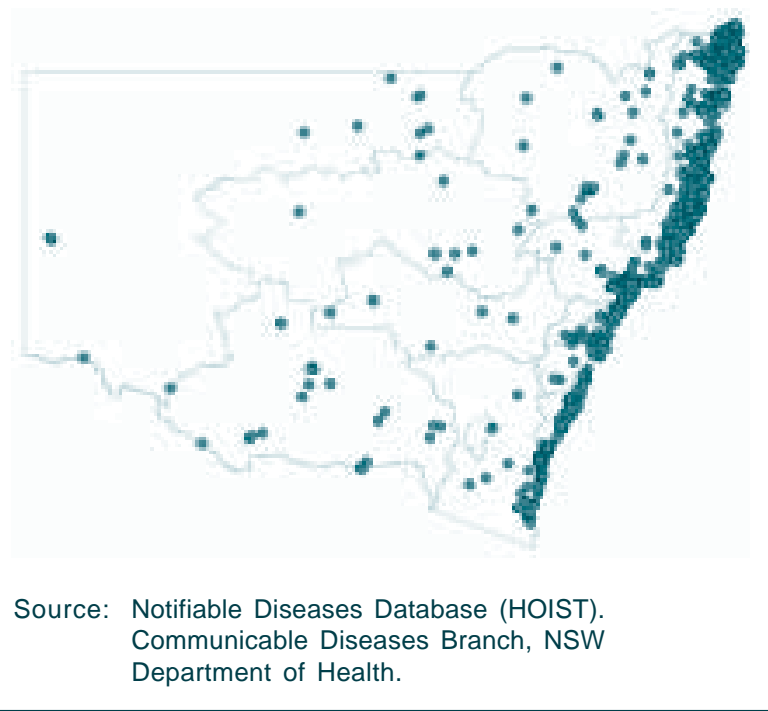

the mid-1980s, which showed that BFV antibodies were highest in residents of coastal areas. ${ }^{14,15}$

While previous reports have described coastal activity, there is some indication of inland rural BFV activity, with

\section{FIGURE 2}

BARMAH FOREST VIRUS INFECTION, ESTIMATED MONTH OF ONSET OF ILLNESS, NEW SOUTH WALES, 1995-2003

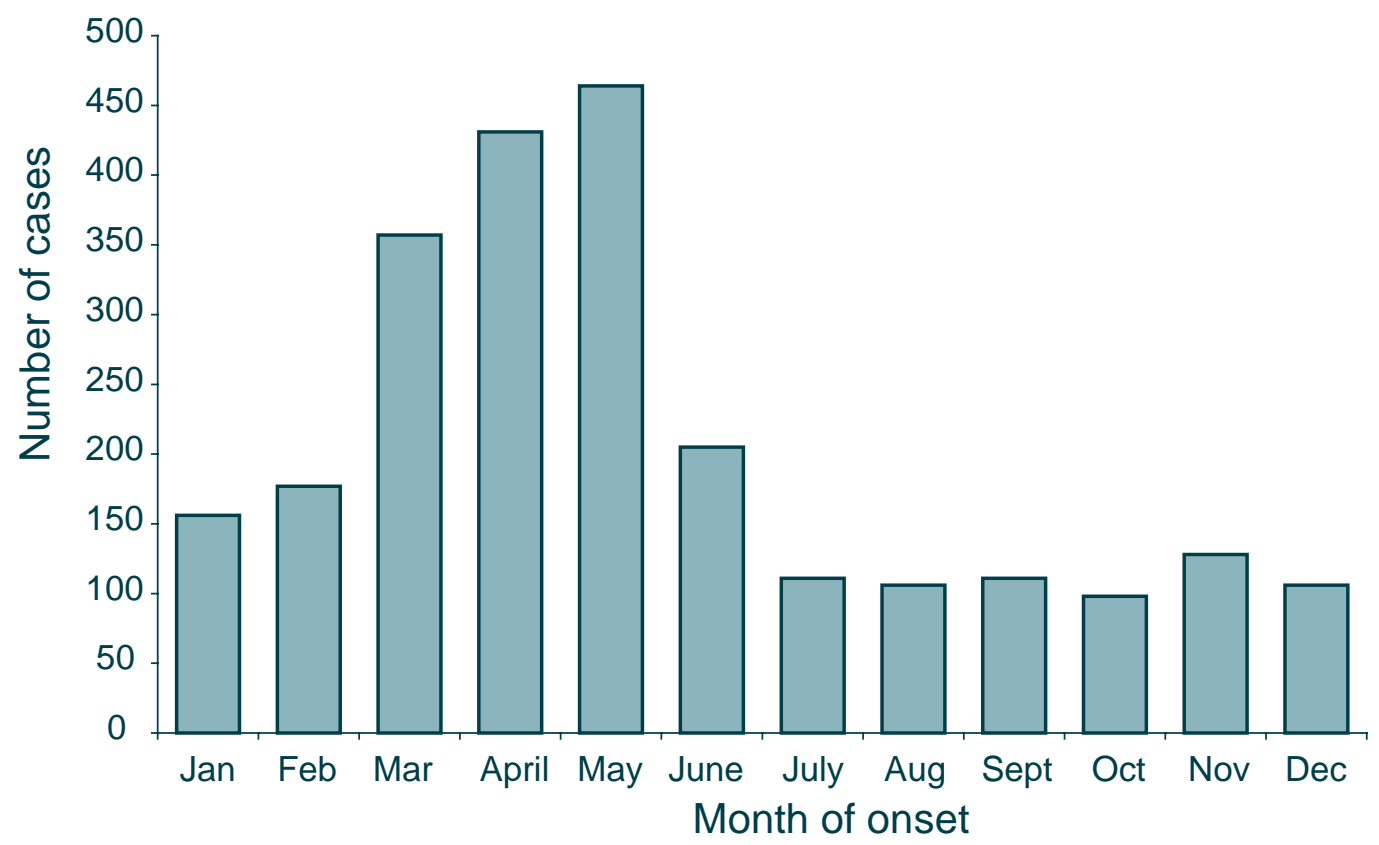

Source: Graphical Online Data Surveillance and Evaluation for Notifiable Diseases (GODSEND). Communicable Diseases Branch, NSW Department of Health. 


\section{FIGURE 3}

BARMAH FOREST VIRUS INFECTION, NOTIFICATIONS BY SEX AND AGE, NEW SOUTH WALES, 1995-2003

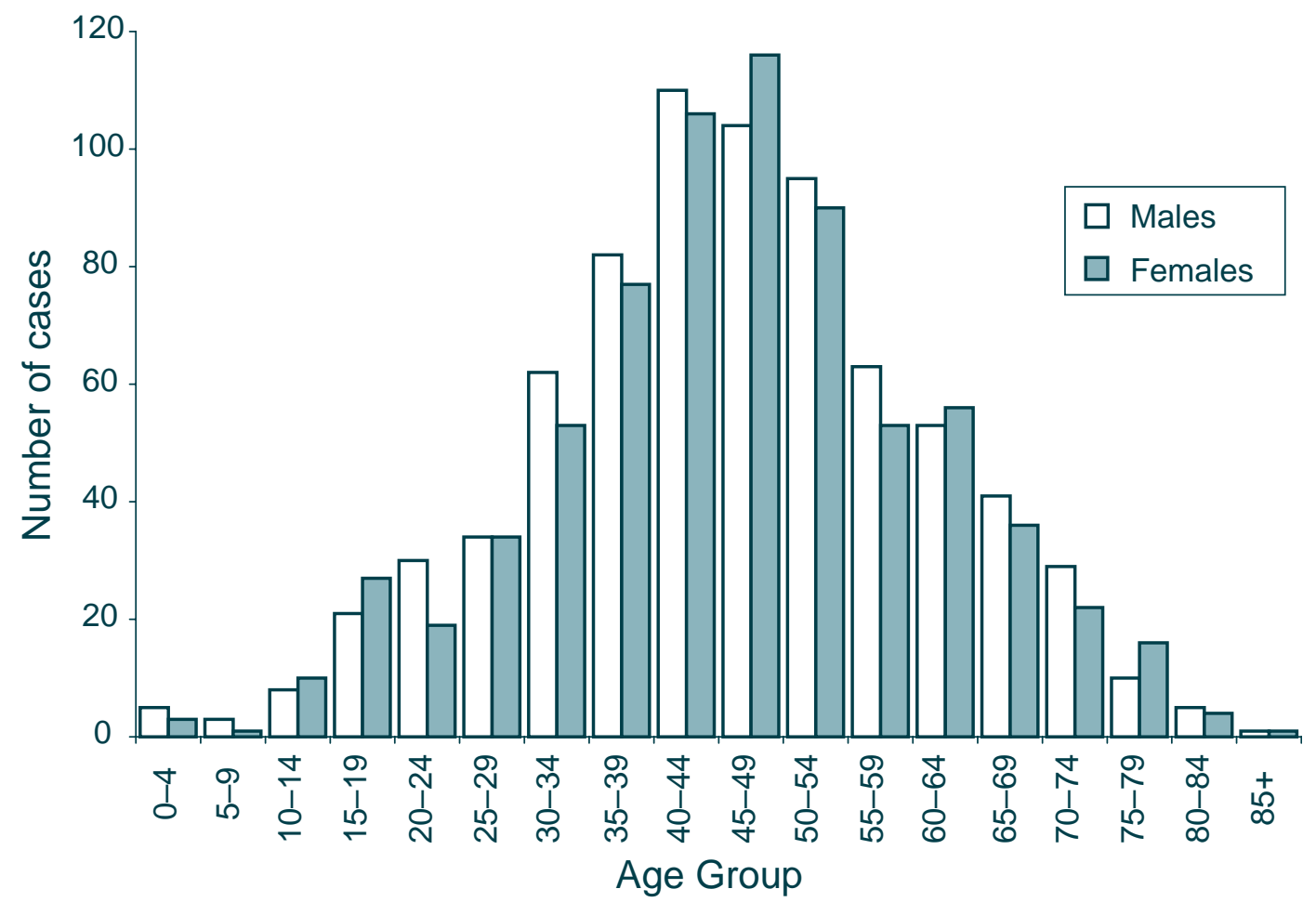

Source: Graphical Online Data Surveillance and Evaluation for Notifiable Diseases (GODSEND). Communicable Diseases Branch, NSW Department of Health.

\section{FIGURE 4}

NOTIFICATIONS OF BARMAH FOREST VIRUS INFECTIONS IN AUSTRALIAN STATES AND TERRITORIES 1995-2003

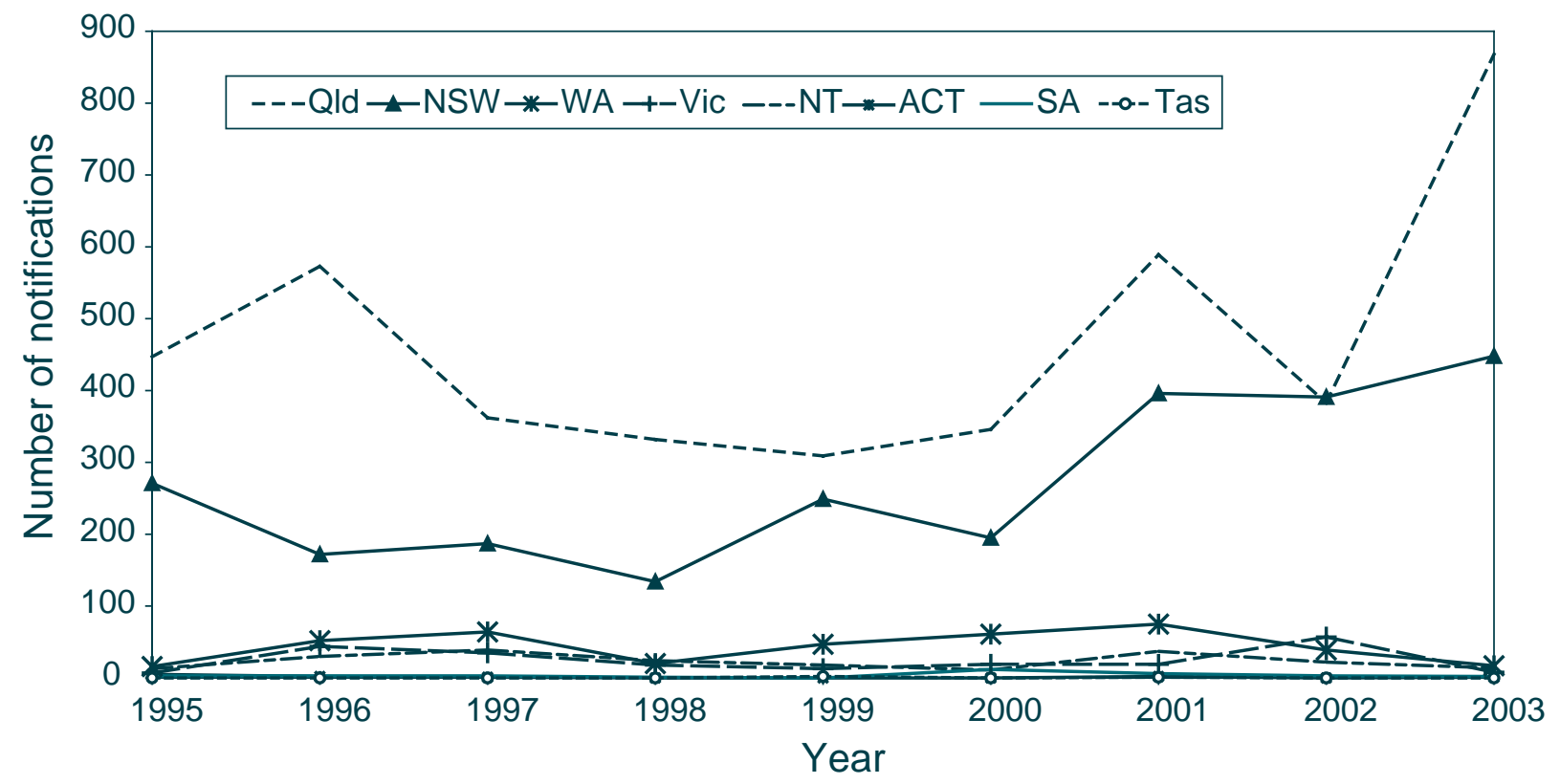

Source: National Notifiable Diseases Surveillance System, Australian Government Department of Health and Ageing. 
notifications being recorded in the Far West Area Health Service. While inland residents may have contracted the infection when visiting coastal areas, there is previous evidence of local vector activity in the inland region, notably a report in 1993 of the identification of BFV isolated from a Culex annulirostris mosquito trapped in Menindee. ${ }^{9}$

On a national level, notifications also rose between 1995 and 2003. There is no obvious annual pattern in notification numbers between the states. In 1996, there was an increase in notifications in Queensland without a corresponding increase in New South Wales. There was an increase in notifications in 2001 in both states, but this was not sustained in Queensland in 2002.

It is difficult to separate the factors that may have contributed to the increase in notifications. Is it a true reflection of increase in virus activity, or does it reflect increased use of BFV-specific serological assays, or increased recognition of clinical disease by doctors, or increased media interest and public awareness of the disease? As the current case definition of suspected BFV infection is based on a single positive BFV-specific IgM, there may be false positive results from commercial assays or inadequate differentiation from other alphaviruses. Ideally, a single positive BFV-specific IgM should be confirmed by another assay or evidence of BFV-specific IgG seroconversion on a convalescent serum sample. On the other hand, early serological testing of suspected clinical cases may be negative, as BFV seroconversion can be slow.

Unlike Ross River virus, relatively little is known about the natural cycle of BFV. The virus is mosquito-borne, and laboratory studies have shown that the saltmarsh mosquitoes Ochlerotatus vigilax, Oc. camptorhynchus, Verrallina funerea and Coquillettida linealis and the freshwater mosquitoes Oc. notoscriptus, Oc. procax and Oc. multiplex are efficient vectors of BFV. ${ }^{1}$ Culex annulirostris (freshwater) has been shown to be a possible but inefficient vector. ${ }^{16}$ Increased numbers of $O c$. vigilax and Oc. camptorhynchus in Western Australia, Oc. camptorhynchus in Victoria and Oc. vigilax in New South Wales have been associated with outbreaks of human disease. Why the BFV cases remain predominantly coastal in distribution when suitable vector habitats occur inland remains unanswered.

Similarly, the reservoir of BFV remains unknown. The reservoirs for Ross River virus include macropods, ${ }^{17}$ possums, ${ }^{18}$ and horses. ${ }^{17}$ Limited serological testing has not found evidence of BFV antibodies in possums and horses. There is some evidence that Macropus giganteus (kangaroo) and Phascolarctos cinereus (koala), ${ }^{19}$ waterbirds, ${ }^{20}$ and cows, ${ }^{17}$ have detectable BFV antibodies and therefore may be potential reservoirs for the virus. Flying foxes have been implicated in the transmission of other viruses in Australia (henipavirus, Australian bat lyssaviruses). Given their coastal distribution they may be implicated in BFV transmission, but this requires further study.

\section{CONCLUSION}

Notifications of BFV infection have increased both nationally and in New South Wales, particularly in the coastal regions of northern parts of the State in the last 3 years. Residents and visitors to the northern coastal areas need to be aware of the importance of taking precautions against mosquito bites. Serosurveys of the human population may be indicated, to determine whether the increase in notifications is either a true reflection of increasing incidence of BFV infection, or reflects the increased awareness of and capacity for testing for the virus. Similarly, as relatively little is known of the natural cycle of BFV, serosurveys of potential reservoir hosts may provide valuable insight to other regions of potential outbreaks.

\section{ACKNOWLEDGEMENTS}

The authors would like to thank Stephen Doggett and Linda Hueston at the Institute of Clinical Pathology and Medical Research for mosquito and laboratory information, and Alan Willmore from the Centre of Epidemiology and Research, NSW Department of Health, for his invaluable assistance with the MapInfo software.

\section{REFERENCES}

1. Russell RC, Dwyer DE. Arboviruses associated with human disease in Australia. Microbes Infect 2000; 2: 1693-1704.

2. Doggett SL, Russell RC, Clancy J, Haniotis J, Cloonan MJ. Barmah Forest virus epidemic on the south coast of New South Wales, Australia, 1994-1995: viruses, vectors, human cases and environmental factors. J Med Entomol 1999; 36(6): 861-868.

3. Beard JR, Trent M, Sam GA, Delpech VC. Self reported morbidity of Barmah Forest virus infection on the north coast of New South Wales. Med J Aust 1997; 167: 525-528.

4. Lindsay M, Johansen C, Broom AK, Smith DW, Mackenzie JS. Emergence of Barmah Forest virus in Western Australia. Emerg Infect Dis 1995; 1(1): 22-26.

5. Passmore J, O' Grady KA, Moran R, Wishart E. An outbreak of Barmah Forest virus disease in Victoria. Commun Dis Intell 2002; 26(4): 600-604.

6. Marshall ID, Woodroofe GM, Hirsch S. Viruses recovered from mosquitoes and wildlife serum collected in the Murray Valley of south-eastern Australia February 1974, during an epidemic of encephalitis. Aust J Exp Biol Med Sci 1982; 60: 457-470.

7. Boughton CR, Hawkes RA, Naim HM. Illness caused by Barmah Forest like virus in New South Wales. Med J Aust 1988; 148: 146-147.

8. Phillips DA, Murray JR, Aaskov JG, Wiemers MA. Clinical and subclinical Barmah Forest virus infection in Queensland. Med J Aust 152: 463-466.

9. Flexman JP, Smith DW, Mackenzie JS, Fraser JR, Bass SP, Hueston L, et al. A comparison of the diseases caused by 
Ross River virus and Barmah Forest virus. Med J Aust 1998; 169: 159-163.

10. Communicable Diseases Surveillance and Control Unit. Notifiable Disease Manual. Sydney: NSW Department of Health, 2002.

11. MapInfo Professional Version 7.0. MapInfo Australia.

12. Muscatello D, McAnulty J. Arboviruses in NSW 1991 to 1999. N S W Public Health Bull 11(11): 190-192.

13. Australian Government Department of Health and Ageing. National Notifiable Diseases Surveillance System. Available at www.cda.gov.au/surveil (accessed 19 February 2004).

14. Vale TG, Carter I, McPhie, James GS, Cloonan J. Human arbovirus infections along the south coast of New South Wales. Aust J Exp Biol Med Sci 1986; 64: 307-309.

15. Hawkes RA, Clement RB, Naim HM, Myrick BA, Ramsay LG. Barmah Forest virus infections in humans in New South Wales. Med J Aust 1987; 146(11): 569-573.
16. Boyd AM, Kay BH. Vector competence of Aedes aegypti, Culex sitiens, Culex annulirostris and Culex quinquefasciatus for Barmah Forest virus. J Med Entomol 1999; 36(4): 508-514.

17. Vale TG, Spratt DM, Cloonan MJ. Serological evidence of arbovirus infection in native and domesticated mammals on the south coast of New South Wales. Aust J Zool 1991; 39: 1-7.

18. Boyd AM, Hall RA, Gemmell RT, Kat BH. Experimental infection of Australian brushtail possums, Trichosurus (Phalangeridae: Marsupialia), with Ross River and Barmah Forest viruses by use of natural mosquito vector system. Am J Trop Med Hyg 2001; 65(6): 777-782.

19. Aldred J, Campbell J, Mitchell G, Davis G, Elliott J. Involvement of wildlife in the natural cycle of Ross River and Barmah Forest viruses. Proceedings from Wildlife Diseases Association Meeting 1991 (unpublished).

20. Russell R. Arboviruses and their vectors in Australia: an update on the ecology and epidemiology of some mosquito borne arboviruses. Rev Med Vet Entomol 1995; 83(4): 141-143. Fit

\section{THE INCREASE IN PRESENTATIONS OF DENGUE FEVER IN NEW SOUTH WALES}

\section{Linda Hueston}

Centre for Infectious Diseases and Microbiology Institute of Clinical Pathology and Medical Research, Westmead

\section{BACKGROUND}

The earliest known reports of dengue fever, a mosquitoborne disease, are from China in 992 AD.${ }^{1}$ During the 18 th and 19th centuries, both the slave trade and increases in shipping and commercial trade saw the disease spread throughout the world via sailing ships. ${ }^{1,2}$ This spread was largely due to the water supplies stored on board ships, which provided an effective means of travel for the virus and vector that cause dengue fever.

The earliest record of dengue fever in Australia is 1873, when 8 cases occurred in Sydney, imported from a ship from Mauritius. ${ }^{3}$ The last epidemic in New South Wales was between 1942 and 1944, and is attributed to troop movements by steam train. ${ }^{4}$ While epidemics of dengue fever have been documented in Queensland, New South Wales, Western Australia and the Northern Territory, it is unlikely that dengue fever has remained endemic between these epidemics. ${ }^{5}$ It is more likely that dengue fever was, and continues to be, reintroduced by tourists or residents returning from overseas countries where dengue fever is endemic. ${ }^{4,6}$ Since 1944 , epidemics have been confined to those areas of Queensland that correspond to the geographic range of the vector mosquito Aedes aegypti. ${ }^{7}$
This confinement may be due to the introduction of reticulated water supplies and the reduction of breeding sites, the combined effect of which has seen the reduction and eradication of the vector mosquito in some areas. ${ }^{4}$ Since 1944, all cases of dengue fever in New South Wales but one have been acquired in Queensland or overseas. The one exception was an infection acquired by a biomedical engineer working with live viruses in the production of diagnostic kits.

In 1991 dengue fever became a notifiable disease in New South Wales. Since then all new laboratory notifications are entered into the NSW Notifiable Diseases Database (NDD), maintained by the Communicable Diseases Branch, NSW Department of Health, and are accessed through the Graphical Online Data Surveillance Evaluation for Notifiable Diseases (GODSEND), maintained by the Centre for Epidemiology and Research, NSW Department of Health. A review of the NDD has shown an increase in the number of notifications of dengue fever over the last 5 years. The Arbovirus and Emerging Diseases Unit, Centre for Infectious Diseases and Microbiology, Institute of Clinical Pathology and Medical Research (Westmead), undertakes a large proportion of dengue virus testing for New South Wales. We have noticed an increase in requests for dengue serology and also an increase in the number of positive notifications between 1999 and 2003. This article describes the pattern of requests and the clinical and travel histories of cases notified through our laboratory, and discusses how these findings relate to the apparent 